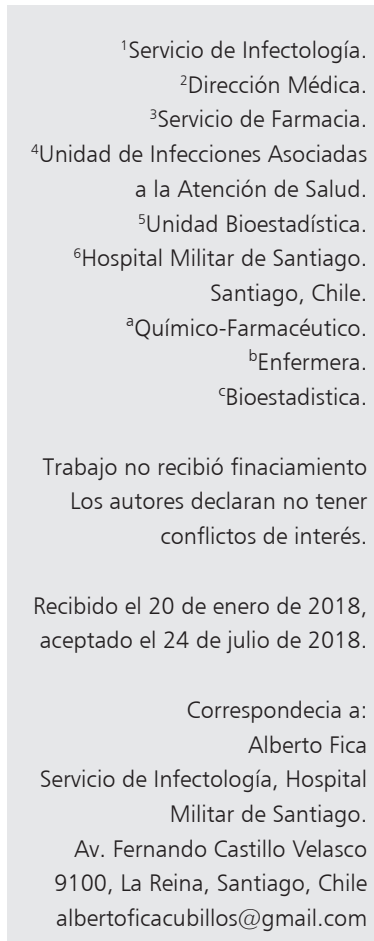

'Servicio de Infectología.

${ }^{2}$ Dirección Médica.

Infecciones Asociadas

a la Atención de Salud.

${ }^{5}$ Unidad Bioestadística.

Santiago, Chile.

bEnfermera.

Bioestadistica.

Trabajo no recibió finaciamiento conflictos de interés.

Recibido el 20 de enero de 2018, aceptado el 24 de julio de 2018.

Correspondecia a: Alberto Fica Mectologia, Hospital Av. Fernando Castillo Velasco albertoficacubillos@gmail.com

\section{Long-term impact of competitive biddings and an antimicrobial stewardship program in a general hospital in Chile}

\author{
ALBERTO FICA ${ }^{1,6}$, CLAUDIA VALENZUELA ${ }^{2,6, a}$, \\ IGNACIO LEIVA ${ }^{3,6, a}$, TERESA VERGARA ${ }^{4,6, b}$, ANDRÉS SOTO $^{1,6}$, \\ JEANNETTE DABANCH ${ }^{1,6}$, PATRICIA MAGUNACELAYA ${ }^{5,6, \mathrm{c}}$
}

\begin{abstract}
Background: The long-term effect of an antimicrobial stewardship program (ASP) and its integrated impact with competitive biddings have been seldom reported. Aim: To evaluate the long-term effect of an ASP on antimicrobial consumption, expenditure, antimicrobial resistance and hospital mortality. To estimate the contribution of competitive biddings on cost-savings. Material and Methods: A comparison of periods prior (2005-2008) and posterior to ASP initiation (2009 and 2015) was done. An estimation of cost savings attributable to ASP and to competitive biddings was also performed. Results: Basal median antimicrobial consumption decreased from 221.3 to 170 daily defined doses/100 beds after the start of the ASP. At the last year, global antimicrobial consumption declined by 28\%. Median antimicrobial expenditure per bed (initially US\$13) declined to US\$ 10 at the first year (-28\%) and to US\$ 6 the last year (-57\%). As the reduction in consumption was lower than the reduction in expenditure during the last year, we assumed that only $48.4 \%$ of savings were attributable to the ASP. According to antimicrobial charges per bed from prior and after ASP implementation, we estimated global savings of US\$ 393072 and US\$ 190000 directly attributable to the ASP, difference explained by parallel competitive biddings. Drug resistance among nosocomial bacterial isolates did not show significant changes. Global and infectious disease-associated mortality per 1000 discharges significantly decreased during the study period $(p<0.05)$. Conclusions: The ASP had a favorable impact on antimicrobial consumption, savings and mortality rates but did not have effect on antimicrobial resistance in selected bacterial strains.

(Rev Med Chile 2018; 146: 968-977)
\end{abstract}

Key words: Antimicrobial Stewardship; Competitive Bidding; Drug Resistance, Bacterial)

\section{Impacto de un programa de control de antimicrobianos (PCA) y licitaciones públicas sobre el consumo de estos medicamentos}

Antecedentes: Existe poca información sobre el impacto a largo plazo de un programa de control de antimicrobianos (PCA) y su efecto combinado con licitaciones públicas de fármacos. Objetivo: Evaluar el impacto de un PCA sobre el consumo, gasto, mortalidad y estimar la contribución de las licitaciones. 
Material y Métodos: Comparación antes (2005-2008) - después (2009-2015) del PCA y estimación porcentual del ahorro atribuible al PCA y licitaciones. Resultados: El consumo bajó de 221,3 a 170 dosis diarias definidas por 100 días camas (medianas) al primer año. En el último año el consumo declinó un 27,6\%. La mediana del gasto por cama ocupada se redujo de 13 a 10 US\$ el primer año y a 6 US\$ el último año (-57\%). Debido a que el gasto bajó más que el consumo, estimamos que solo el 48,4\% del ahorro fue debido al PCA (cuociente de ambas reducciones: -27,6\%/-57\%). De acuerdo con el gasto en antimicrobianos por cama entre ambos períodos, se calculó un ahorro global de 393.000 US\$ y de 190.000 US\$ directamente atribuible al PCA, siendo la diferencia explicada por licitaciones. Los porcentajes de resistencia en cepas de infecciones nosocomiales no mostraron incrementos o reducciones significativas en el tiempo y la mortalidad por egresos asociada a enfermedades infecciosas (Códigos CIE 10) se redujo significativamente $(p<0,05)$. Conclusiones: $E l$ PCA se asoció a largo plazo a un impacto favorable sobre el consumo de antimicrobianos, gasto por antimicrobianos y egresos por enfermedades infecciosas sin un impacto en la resistencia antimicrobiana. Las licitaciones tuvieron un efecto aditivo en el ahorro.

Palabras clave: Control de antimicrobianos; Licitaciones públicas; Resistencia a drogas.

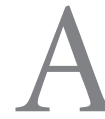
ntimicrobial control is imperative due to emergence of resistant isolates, shortage of therapeutic drugs, risk of clinical failure and mortality, and expenditure increases ${ }^{1,2}$. Recently, a global program has been issued by WHO asking to adopt different strategies to control this threat ${ }^{3}$. Effective interventions for hospitals have been delineated and the impact on consumption, expenditure, and sometime antibiotic resistance has been supported by systematic reviews ${ }^{4,5}$. These interventions require financial investment to hire human resources, and support differente activities. Chile has a governmental regulation issued by the Ministry of Health since 1999 in order to implement antimicrobial stewardship programs (ASP) in hospitals that has never been supervised, and studies developed more a decade ago showed partial fulfillment ${ }^{6}$. Literature on the impact of ASP in Chile is scarce ${ }^{7,8}$ and probably explained by the low number and the geographically concentrated distribution of infectious diseases (ID) specialists. Novel information on the impact of ASP on consumption, cost-saving, antimicrobial resistance, and mortality, is needed to convince hospital administrators to invest in dedicated human resources. In addition, most of the evidence available refers to short-term impacts, usually for less than 2 years ${ }^{5}$ with few reports measuring the effect beyond this frametime ${ }^{9}$. On ther hand, a progressive trend for competitive biddings with prequalified pharmaceutical providers, has been adopted in different hospitals, countries or worldwide programs allowing cheapest drug prices ${ }^{10,11}$. This policy may influence cost saving and its contribution should be measured when ASP are also implemented.

We aimed to evaluate the long-term impact of an ASP in a general hospital in Chile, its effect on consumption, mortality, expenditure and antimicrobial resistance. Besides, as competitive biddings occurred in parallel to the ASP, the relative importance of them was estimated.

\section{Material and Methods}

\section{Study design and setting}

Observational study that compared pre (20052008) and post ASP (2009 and 2015) periods. It was performed at the Hospital Militar of Santiago, a centre that attends active and retired military personnal and their relatives, as well as general public.

\section{ASP}

The ASP begun at year 2009 and was performed by 3 ID specialists during working days using a list of restricted antibiotics prepared daily by the Pharmacy Unit. The program was executed as a direct clinical visit using a prospective audit format with feedback to physicians in charge. The list of 
restricted molecules include $2^{\text {nd }}$ to $4^{\text {th }}$ generation cephalosporins, parenteral beta-lactam/beta-lactam inhibitors, parenteral quinolones, aminoglycosides, clindamycin, vancomycin, linezolid, tigecycline, antifungals and parenteral antiviral compounds. Supervision by ID specialists was allowed to stop or modify a prescription. The ASP included 3 courses on the period on antimicrobial use directed to medical staff and weekly seminars organized by the ID Unit. Besides, resident physicians in internal medicine were required to rotate during two months at the ID Unit to enhance their training. Most of them made night shifts taking initial decisions on therapy and were also in charge of medical wards. Only one guideline was available during the study period (surgical antimicrobial prophylaxis).

\section{Antimicrobial consumption}

Consumption was evaluated only in adult patients by daily defined doses (DDD) per 100 occupied beds, and sepatared by general wards and critical and intermediate care beds (CCU beds). Psychiatrics beds were excluded. Specific DDD were obtained at the WHO Collaborating Centre for Drug Statistics Methodology ${ }^{12}$. Bed occupancy was provided by the Biostatistical Unit of the hospital. Comparison was made by median values from the pre ASP era (2005 to 2008) with those of years 2009 and 2015 (ASP period). Data from intermediate years was not available (2011 to 2014). Antituberculosis and antiretrovirals drugs were not included because they are dispensed by a central governamental office. Trends were analyzed by Spearman correlation coefficient.

\section{Expenditure}

Data on antimicrobial charges, including taxes, was available from 2006. Values were upgraded to june 2015 using an online software from the Instituto Nacional de Estadísticas of Chile and converted to US dollars taken the parity change of the same month (1 US\$ $=629.99$ CLP). We calculated the annual expenditure per occupied bed (quotient of expenditure per bed occupancy) and compared variation as percentual changes from the basal value (median value from the pre ASP period). Trends were analyzed by Spearman correlation coefficient.

\section{Antimicrobial resistance and nosocomial rates \\ To avoid contamination of data with commu- nity-acquired infections, we only included strains}

detected by active surveillance of nosocomial infections with only one isolate per patient, and excluding carrier cases. This information was available from 2010. Percentual changes were explored for methicillin-resistant Staphylococcus aureus, third generation-resistant Escherichia coli and Klebsiella pneumoniae isolates, as well as, carbapenem-resistant Pseudomonas aeruginosa strains. Changes in density rate (number of resistant isolates per occupied beds) were also analyzed. In all cases, trends were analyzed by Spearman correlation coefficient. Changes in nosocomial rates were also analyzed as detected by active surveillance of central venous catheter-associated bloodstream infections, ventilator-associated pneumonia, bloodstream infection related to hemodialysis catheter, urinary tract infection associated to indwelling catheter, vaginal or cesarean postpartum endometritis, and wound infections for clean or clean-contaminated surgical procedures at different sites. Besides, density rates of new events of Clostridium difficile diarrhea (first episode) and clinical infections associated to vancomycin-resistant Enterococci (VRE) were registered. Trends in nosocomial infections were analyzed by Spearman correlation coefficient.

\section{Competitive biddings}

Four open calls were issued between 2008 and 2014 for competitive biddings in order to provide all the pharmaceutical products used at the hospital. Selection was performed by predefined criteria looking for the best quality/price relationship. Only prequalified providers were allowed to participate.

\section{Global mortality and mortality associated to infectious diseases codes}

A possible effect of the ASP on global mortality or that associated to ID according to the International Classification of Diseases $10^{\text {th }}$ revision (ICD codes A00-B99), was analyzed by adult death rates by 1000 discharges and trends analyzed. Information on deceased patients and specific ICD was obtained from the Biostatistics Unit. Discharges from the psychiatric unit were excluded. Data was available from 2005 to 2015 .

\section{Ethical issues}

This work was approved by the institutional review board. 


\section{Results}

\section{Antimicrobial consumption}

Median basal consumption decreased from $221.3 \mathrm{DDD} / 100$ beds to $170 \mathrm{DDD} / 100$ beds after the ASP begun (Table 1). Consumption maintained the decreasing trend after the first year
(-18.8\%), and towards 2015, global consumption had declined $27.6 \%$ when compared with the median basal value. Reduction was observed both at CCU and general wards, but were not significant (Table 1). Falling was driven by decreasing trends in antibiotic consumption and antifungal consumption (Tables 1 and 2). Antivirals con-

Table 1. Antibiotic consumption in DDD per 100 occupied beds before and after ASP implementation at the Hospital Militar, Chile

\begin{tabular}{|c|c|c|c|c|c|}
\hline Compound & $\begin{array}{l}\text { Median } \\
\text { pre ASP* }\end{array}$ & $\begin{array}{l}\text { Median post } \\
\text { ASP }\end{array}$ & $\begin{array}{c}\text { Median } \\
\text { difference** }\end{array}$ & $\begin{array}{c}\text { Spearman } \\
\text { correlation } \\
\text { coefficient } \\
\text { r }\end{array}$ & $\mathbf{p}$ \\
\hline All & 221.3 & 170.0 & -51.3 & -0.48 & $\mathrm{~ns}^{* * *}$ \\
\hline General wards & 65.3 & 55.0 & -10.3 & -0.77 & ns \\
\hline CCU beds & 157.2 & 115.0 & -42.2 & -0.48 & ns \\
\hline All antibiotics & 211.8 & 139.2 & -72.6 & -0.48 & ns \\
\hline Antibiotics at CCU & 147.7 & 110.2 & -37.5 & -0.42 & ns \\
\hline Antibiotics at wards & 63.0 & 53.3 & -9.7 & -0.77 & ns \\
\hline All beta-lactams & 114.4 & 62.8 & -51.6 & -0.82 & $<0.05$ \\
\hline Penicillins & 29.1 & 24.6 & -4.5 & -0.65 & ns \\
\hline Piperacillin-tazobactam & 4.6 & 10.2 & $+5,6$ & +0.94 & $<0.05$ \\
\hline All Cephalosporins & 68.5 & 50.1 & -18.4 & -1.00 & ns \\
\hline 1st G Cephalosporins & 20.5 & 13.1 & -7.4 & -1.00 & ns \\
\hline 2nd G Cephalosporins & 2.4 & 0.5 & -1.9 & -0.94 & $<0.05$ \\
\hline 3rd G Cephalosporins & 35.8 & 35.9 & +0.1 & +0.54 & ns \\
\hline 4th G Cephalosporins & 9.8 & 0.7 & -9.1 & -1.00 & ns \\
\hline All carbapenems & 16.3 & 14.1 & -2.2 & +0.08 & ns \\
\hline Imipenem & 10.6 & 4.2 & -6.4 & -0.48 & ns \\
\hline Meropenem & 3.6 & 8.5 & +4.9 & +0.46 & ns \\
\hline Ertapenem & 2.4 & 1.4 & -1.0 & -0.42 & ns \\
\hline All quinolones & 27.6 & 18.3 & -9.3 & -0.48 & ns \\
\hline All aminoglycosides & 3.8 & 5.6 & +1.8 & +0.14 & ns \\
\hline All glycopeptides & 15.3 & 10.4 & -4.9 & -0.48 & ns \\
\hline All macrolides & 2.5 & 0.9 & -1.6 & -0.82 & $<0.05$ \\
\hline Clindamycin & 8.8 & 6.2 & -2.6 & -0.88 & $<0.05$ \\
\hline Metronidazole & 14.4 & 13.8 & -0.6 & -0.48 & ns \\
\hline Cotrimoxazole & 15.0 & 11.4 & -3.6 & +0.25 & ns \\
\hline Linezolid & 0.4 & 1.0 & +0.6 & +0.72 & ns \\
\hline Colistin & 0.7 & 2.0 & +1.3 & +0.65 & ns \\
\hline Tigecycline & 0.1 & 1.2 & +1.1 & +0.92 & $<0.05$ \\
\hline
\end{tabular}

*:ASP: Antimicrobial stewardship program; **: a negative value indicates a reduction in consumption; a positive value an increase: ${ }^{* *}$ ns: non significant. 
Table 2. Antifungal consumption in DDD per 100 occupied beds before and after ASP implementation at the Hospital Militar, Chile

\begin{tabular}{|lccccc|}
\hline Compound & $\begin{array}{c}\text { Median Pre } \\
\text { ASP* }\end{array}$ & $\begin{array}{c}\text { Median Post } \\
\text { ASP }\end{array}$ & $\begin{array}{c}\text { Median differ- } \\
\text { ence** }\end{array}$ & Spearman & p \\
All antifungal & 9.0 & 6.2 & -2.8 & -0.65 & $\mathrm{~ns}$ *** \\
Antifungal at CCU & 7.0 & 4.6 & -2.4 & -0.20 & $\mathrm{~ns}$ \\
Antifungal at wards & 1.7 & 1.6 & -0.1 & -0.54 & $\mathrm{~ns}$ \\
All Echinocandines & 2.4 & 0.9 & -1.5 & -0.82 & $<0.05$ \\
Caspofungin & 2.4 & 0.0 & -2.4 & -0.98 & $<0.05$ \\
Anidulafungin & 0.0 & 0.9 & +0.9 & +0.94 & $<0.05$ \\
Amphotericin deoxycolate & 0.6 & 0.3 & -0.3 & -0.82 & $<0.05$ \\
Fluconazole & 6.3 & 5.0 & -1.3 & -0.17 & $\mathrm{~ns}$ \\
Voriconazole & 0.1 & 0.0 & -0.1 & -0.65 & $\mathrm{~ns}$ \\
\hline
\end{tabular}

*: ASP: Antimicrobial stewardship program; **: a negative value indicates a reduction in consumption; a positive value an increase; ${ }^{* *}$ : ns: non significant.

sumption did not change appreciably (median consumption 0.62 to $0.58 \mathrm{DDD} / 100$ beds).

Analysis on antibiotic showed significant reductions among beta-lactams (median difference $-51.6 \mathrm{DDD} / 100$ beds, $\mathrm{r}=-0.87$ ) and macrolides (median difference -1.6 DDD/100 beds, $\mathrm{r}=-0.82$;
Table 1 and Figure 1). Among beta-lactams, a marked decreasing trend was observed for first and fourth generation cephalosporins, ertapenem, imipenem, penicillins, quinolones, glycopeptides, metronidazole, and cotrimoxazole (Table 1, Figure 1). Clindamycin and second

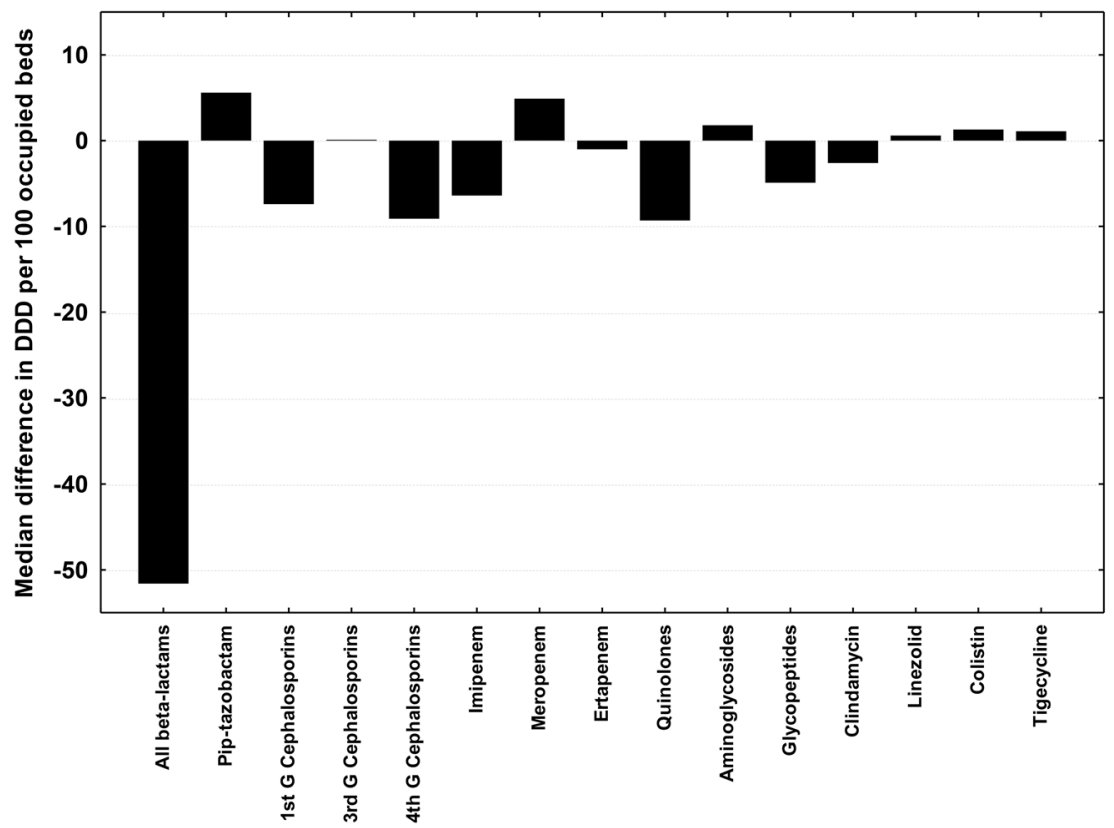

Figure 1. Impact of the ASP on different antibiotic compounds. 
generation cephalosporins consumption decreased significantly.

During the study period, consumption significantly increased for piperacillin-tazobactam (median difference $+5.6 \mathrm{DDD} / 100$ beds, $\mathrm{r}=+0.94)$, and tygecyline (median difference +1.1 DDD/100 beds, $r=+0.93$ ). This was accompanied by similar but not significant trends for third generation cephalosporins, meropenem, aminoglycosides, linezolid, and colistin (Table 1, Figure 1). A replacement phenomenon on carbapenems preference was perceived: increases in meropenem consumption were accompanied by a parallel reduction in ertapenem and imipenem prescription with no global expansion of these compounds (Table 1, Figure 1).

Antifungals prescription preferences also changed. Caspofungin consumption was totally replaced by anidulafungin (Table 2, Figure 2). Voriconazole and fluconazole consumption showed decreasing trends. Amphotericin deoxycolate consumption decreased.

\section{Nosocomial infection rates}

Most nosocomial infection rates under surveillance in adult patients did not demonstrate significant variations during the analyzed period. They included those associated to invasive procedures, vaginal or cesarean postpartum endometritis, and wound infections for clean or clean-contaminated surgical procedures at different sites (data not shown). Only infections associated to total hip replacement significantly rise between 2005 and 2015 (2.1\% to 3.3\%; $\mathrm{r}=+0.94, \mathrm{p}<0.05)$. These results suggest that variation in nosocomial infection rates appear not have induced antimicrobial consumption modifications. On the other hand, density rate of new events of diarrhea associated to $C$. difficile ( 0.4 to 0.1 events per 1000 bed-days between 2010 and 2015; $r=-0.88, p<0.05)$ and clinical infections linked to VRE ( 0.14 to 0.04 between 2003 and 2015; $r=-0.71$ ), significantly lowered during or after ASP begun.

\section{Economic impact}

Global antimicrobial expenditure per bed plummeted from a median of 13 to 10 US $\$$ at the second year $(2010,-28 \%)$, and to US\$ 6 during year $2015(-57 \%)$. For CCU, values descended from a median of US\$ 59 to 36 per bed at 2010 $(-23 \%)$, and to US\$ 15 per bed at year 2015

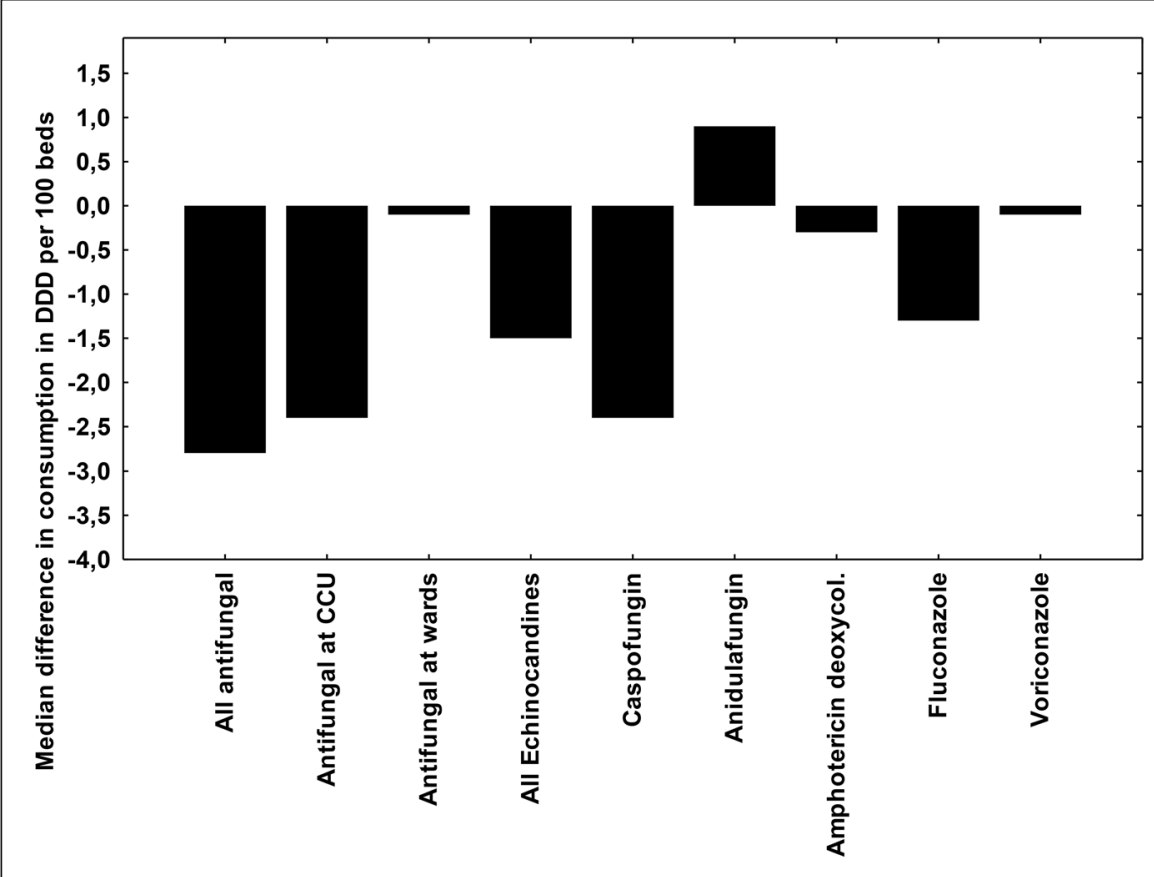

Figure 2. Impact of the ASP on different antifungal compounds. CCU: Critical Care Units. 
$(-75 \%)$. For general wards, changes were similar: 7 to 6 US\$ per bed $(-12 \%)$ at 2010 and to US\$ 5 per bed at $2015(-32 \%)$. These variations were significant for CCU $(r=-0.90, p<0.05)$. However, not all this saving is attributable to reduced antimicrobial consumption. Consumption decreased $27.6 \%$ but expenditure lower further $(-57 \%)$ at the last year of the study. We assumed that only a fraction of cost-saving were related to the impact on consumption (the difference by biddings), and calculated this factor at the last year as the proportion obtained from the quotient consumption/ cost-saving (-27.6\%/-57\%), given an estimate of $48.4 \%$ as a direct contribution of the ASP. That means that at the last year of follow up, approximately half of the impact on expenditure was explained by the control program, and the other half by competitive biddings (Figure 3 ).

The next step was to estimate cost-saving in currency. Antimicrobial charges per occupied bed from 2005 to 2008 were taken as the basal value (median US\$ 13 per bed). This cost was multiplied by the number of total occupied beds, allowing estimate the pre ASP global charge on antimicrobials. The same formula was applied for 2015 using this time US\$ 6 per occupied bed. Using this approach, it was estimated that during the last year, cost-saving reached 393072 US\$. Nonetheless, only $48.4 \%$ of this amount was estimatively attributable to the ASP, an amount equivalent to 190000 US\$.

\section{Antimicrobial resistance trends}

During years 2010 to 2015, 42 S. aureus, 40 E. coli, 23 K. pneumoniae, and 41 P. aeruginosa isolates were identified associated to different nosocomial infections. Analysis of percentual changes of resistant isolates did not show significant variations (data not shown). Density rates (number of resistant isolates belonging to any one of these groups expressed by occupied beds), also remain stationary (data not shown). No information was available from the pre ASP era.

\section{Global mortality and infectious diseases-associated mortality trends}

From 2005 to 2015, a significant reducing trend was observed both for global mortality (31 to 25 per 1000 discharges; $\mathrm{r}=-0.72, \mathrm{p}<0.05)$ and infectious diseases-associated mortality ( 4 to 2 per 1000 discharges; $r=-0.81, p<0.05$, Figure 4 ).

\section{Discussion}

Our results demonstrate that our ASP was associated with a favorable impact on antimicrobial consumption, cost-saving and ID-related

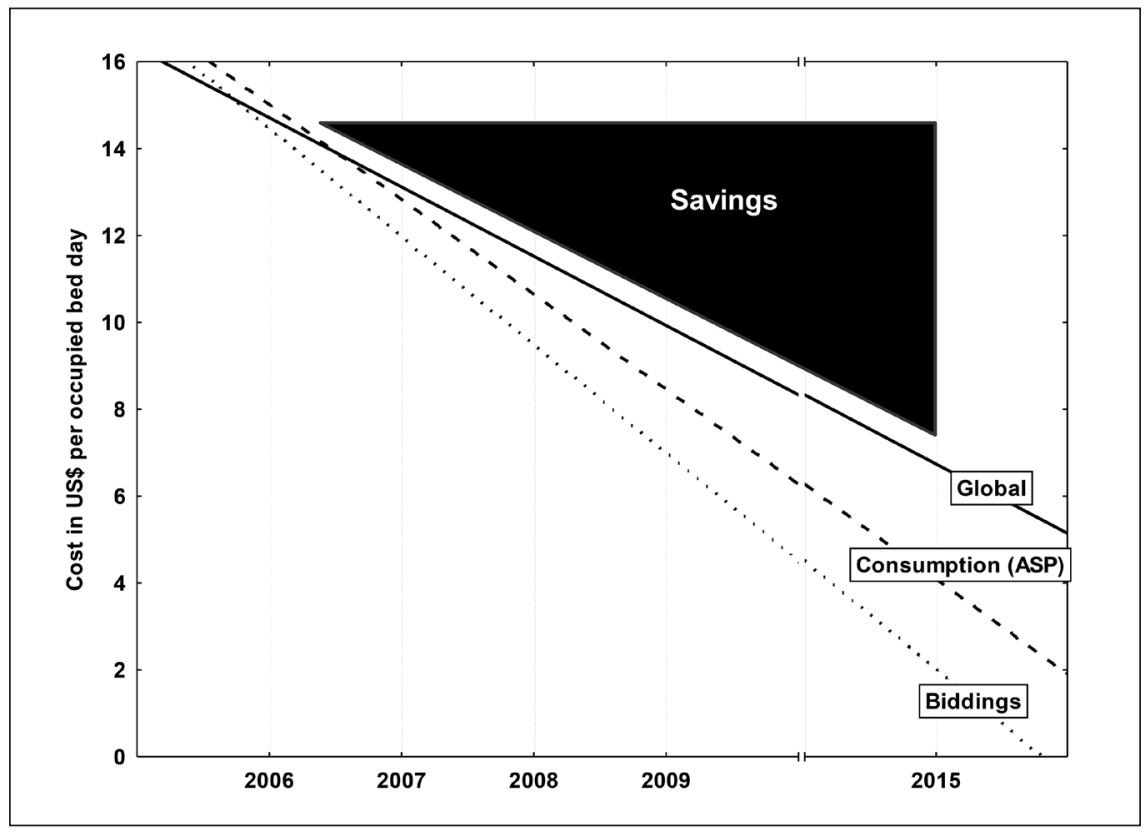

Figure 3. Fitted linear regression curves of antimicrobial expenditure per occupied bed-day at pre (2006-2008) and post ASP initiation era (2009 and 2015). Contribution of competitive biddings (4 since 2008) increased over time: at year 2015, almost half of cost-saving was explained by the ASP; the other half by competitive biddings. 
mortality. The effect intensified along time and involved different compound families. Results on expenditure were more pronounced than those attributable to consumption reduction, indicating an additive effect of sequential competitive biddings. Approximately, for every two dollars saved, one was achieved by the ASP. Besides, as salaries of the 3 ID specialists involved in control reached US\$ 130000 per year and savings were of a higher magnitude the program itself was sustainable. This information is useful to convince hospital administrators in order to support initial hiring of dedicated human resources dedicated to ASP as has been shown in other reports ${ }^{5,7,8,13-22}$. To the best of our knowledge, this is the first report that analyzes the contributory role of bidding and ASP at the same time. In addition, we believe our results are relevant because information on the long-term effect of ASP is scarce ${ }^{9,23}$, and as shown here, the impact appears to deepen along time. In our hospital, consumption decline appears not to be linked with a parallel reduction in most nosocomial infection rates.

Consumption increase involved few molecules, and probably by desired reasons. Piperacillin-tazobactam was frequently used in CCU patients in prolonged infusion ${ }^{24}$, replacing alternatives.
Tygecycline use in polymicrobial multiresistant infections, avoided simultaneous use of carbapenems and glycopeptides (off label indication) ${ }^{25}$. On the other hand reduction in caspofungin and ertapenem utilization obeyed to their higher cost in comparison with suitable alternatives in their respective families.

Despite data on antimicrobial resistance was not available from the pre ASP era, trend analysis did not evidence a declining pattern for none of the species. In contrast, most of the literature describes antimicrobial resistance among inpatient-associated isolates without indicating how much of them could be related to readmitted or transferred patients. The declining curve on $C$. difficile- associated diarrhea or clinical infections linked to VRE could be interpreted as a successful accomplishment of the ASP. Nonetheless, both problems were specifically managed by the nosocomial infection control group with dedicated intervention programs that started almost in parallel to the ASP, turning difficult to read the contribution of each separately.

A favorable impact of ASP on mortality has rarely been reported for ICU or medical ward patients $s^{9,26}$, and our results suggests an additional benefit of these programs. The effect was

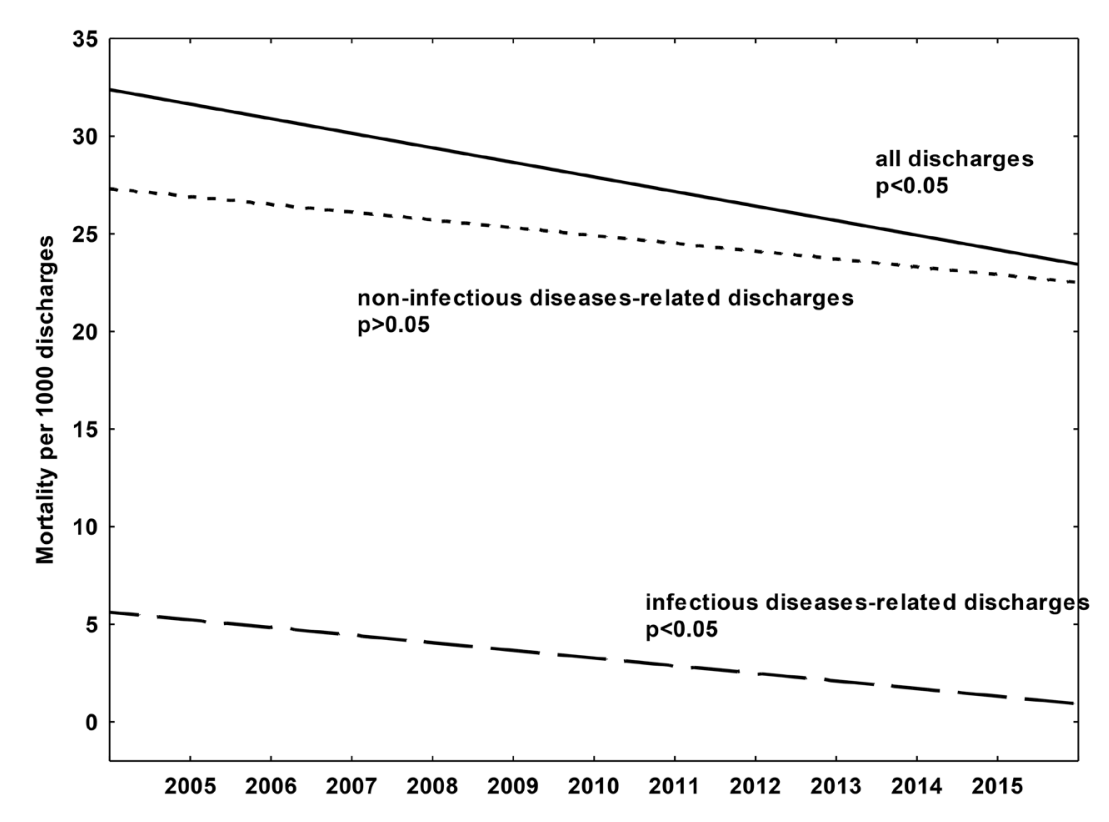

Figure 4. Fitted linear regression curves of all-cause mortality, non-infectious and infectious-related mortality during the study period. See text for details. 
observed on global mortality and explained by a significant impact on infectious disease-related deaths. Several reports and reviews support a beneficial impact of ID consultations on mortality through several scenarios in general hospital or ICU settings, S. aureus or Candida bloodstream infections, infectious endocarditis or infectious complications on solid organ transplant patients $^{27-32}$.

This work has some limitations. Data on consumption on intermediate years after the ASP begun was not available, making theoretically possible years with higher antimicrobial prescription. We believe this is improbable because the working format remain, the effect augmented along time and expenditure also plummeted. The hospital moved to a new building on 2009, the same year ASP begun. The new facility diminished patient numbers per room (from 6 to 3 or 2), a fact that could have decrease nosocomial infection rates and antimicrobial use. Our results suggest that this explanation is highly improbable because neither nosocomial infections rates nor antimicrobial resistant isolates change appreciably during the study period. Aditionally, a transversal impact over several families of antimicrobial compounds was observed, not only for those applied in nosocomial infections management, and the positive impact was maintained and deepened several years after the hospital moved out. In addition, it is unknown if more educational activities, more antimicrobial guidelines or better diagnostics technologies could have had a more pronounced impact on consumption. Furthermore, severity scores were not included in our work and it is possibly that less severely ill patients predominate after ASP begun. If that were the case, non-infectious related mortality should have also fade away, but this phenomenon did not occur making unlikely this explanation.

In conclusion, our ASP was associated in the short- and long-term with a favorable impact on antimicrobial consumption, expenditure, and decreased mortality. Parallel competitive biddings amplified control expenditure obtained by the ASP. The program was sustainable as salaries of ID specialists participating in the ASP were lower than savings obtained. Using only information linked to nosocomial isolates, we could not demonstrate a reversion in antimicrobial resistance.

\section{References}

1. Executive Office of the President. President's Council of Advisors on Science and Technology. Report to the President on combating antibiotic resistance. September 2014. Disponible en: https://www.whitehouse.gov/sites/ default/files/microsites/ostp/PCAST/pcast_carb_report_sept2014.pdf [Consultado el 26 de noviembre de 2017].

2. World Health Organization. Antimicrobial Resistance. Global report on surveillance. 2014. Disponible en: http://apps.who.int/iris/bitstre am/10665/112642/1/9789241564748_eng.pdf [Consultado el 26 de noviembre de 2017].

3. World Health Organization. Global action plan on antimicrobial resistance. 2015. Disponible en: http://apps. who.int/iris/bitstream/10665/193736/1/9789241509763_ eng.pdf [Consultado el 26 de noviembre de 2017].

4. Barlam TF, Cosgrove SE, Abbo LM, MacDougall C, Schuetz AN, Septimus EJ, et al. Implementing an Antibiotic Stewardship Program: Guidelines by the Infectious Diseases Society of America and the Society for Healthcare Epidemiology of America. Clin Infect Dis 2016; 62 (10): 1197-202.

5. Karanika S, Paudel S, Grigoras C, Kalbasi A, Mylonakis E. Systematic review and meta-analysis of clinical and economic outcomes from de implementation of hospital-based antimicrobial stewardship programs. Antimicrob Agents Chemother 2016; 60 (8): 4840-52.

6. Fica A, Cabello A, Juliet C, Prado P, Bavestrello L. Consumo de antimicrobianos parenterales en diferentes hospitales en Chile durante el 2005. Rev Chilena Infectol 2008; 25 (6): 419-27.

7. Wolff M. Resultados de un programa de control sobre el uso de antibióticos. Rev Med Chile 1984; 112 (11): 1096-103.

8. Lira G, Giglio MS, Zúñiga M, Pinto ME. Consumo de antimicrobianos y variación en la resistencia en bacilos Gram negativos en un período de 10 años: Hospital San Juan de Dios-Chile. Rev Chilena Infectol 1999; 16: 199210.

9. Chen IL, Lee CH, Su LH, Wang YL, Liu JW. Effects on implementation of an online comprenhensive antimicrobial-stewardship program in ICUs: A longitudinal study. J Microbiol Immunol Infect 2016; pii: S16841182(16)30068-8.

10. Lunte K, Cordier-Lassalle T, Keravec J. Reducing the price of treatment for multidrug-resistant tuberculosis trough the global drug facility. Bull World Health Organ 2015; 93 (4): 279-82.

11. Al-Abbadi I, Qawwas A, Jaafreh M, Abosamen T, Saket 
M. One-year assessment of joint procurement of pharmaceuticals in the public health sector in Jordan. Clin Ther 2009; 31 (6): 1335-44.

12. WHO Collaborating Centre for Drug Statistics Methodology. Disponible en: https://www.whocc.no/ddd/ definition_and_general_considera/ [Consultado en diferentes fechas el año 2016].

13. Apisarntharanak A, Danchaivijitr S, Khawcharoenporn T, Limsrivilai J, Warachan B, Bailey TC et al. Effectiveness of education and an antibiotic-control program in a tertiary care hospital in Thailand. Clin Infect Dis 2006; 42 (6): 768-75.

14. Bantar C, Sartori B, Vesco E, Heft C, Saúl M, Salamone $\mathrm{F}$ et al. A hospitalwide intervention program to optimize the quality of antibiotic use: Impact on prescribing practice, antibiotic consumption, cost savings, and bacterial resistance. Clin Infect Dis 2003; 37 (2): 180-6.

15. Bantar C, Vesco E, Heft C, Salamone F, Krayeski, Gomez $\mathrm{H}$ et al. Replacement of broad-spectrum cephalosporins by piperacillin-tazobactam: Impact on sustained high rates of bacterial resistance. Antimicrob Agents Chemother 2004; 48 (2): 392-95.

16. Beovic B, Kreft S, Seme K, Cizman M. The impact of total control of antibiotic prescribing by infectious disease specialist on antibiotic consumption and cost. J Chemother 2009; 21 (1): 46-5.

17. Micek ST, Ward S, Fraser VJ, Kollef MH. A randomized controlled trial of an antibiotic discontinuation policy for clinically suspected ventilator-associated pneumonia. Chest 2004; 125 (5): 1791-9.

18. Peto Z, Benko R, Matuz M, Csullog E, Molnar A, Hajdu E. Results of a local antibiotic management program on antibiotic use in a tertiary intensive care unit in Hungary. Infection 2008; 36 (6): 560-4.

19. Sáez-Llorens X, Castrejón de Wong MM, Castaño E, De Suman O, De Morös D, De Atencio I. Impact of an antibiotic restriction policy on hospital expenditures and bacterial susceptibilities: a lesson from a pediatric institution in a developing country. Pediatr Infect Dis J 2000; 19 (3): 200-6.

20. Uçkay I, Vernaz-Hegi N, Harbarth S, Stern R, Legout L, Vauthey L, et al. Activity and impact on antibiotic use and costs of a dedicated infectious diseases consultant on a septic orthopaedic unit. J Infect 2009; 58 (3): 20512.

21. Rosa RG, Goldani LZ, dos Santos RP. Association between an adherence to an antimicrobial stewardship program and mortality among hospitalized cancer patients with febrile neutropenia: a prospective cohort study. BMC Infect Dis 2014;14:286.

22. Okumura LM, Silva MM, Veroneze I. Effects of a bund- led antimicrobial stewardship program on mortality: a cohort study. Braz J Infect Dis 2015; 19 (3): 246-52.

23. Rüttiman S, Keck B, Hartmeier C, Maetzel A, Bucher HC. Long-term antibiotic cost savings from a comprehensive intervention program in a medical department of a university-affiliated teaching hospital. Clin Infect Dis 2004; 38 (3): 348-56.

24. Abdul-Aziz MH, Lipman J, Akova M, Bassetti M, De Waele JJ, Dimopolos G, et al. Is prolonged infusion of piperacillin/tazobactam and meropenem in critical ill patients associated with improved pharmacokinetics/ pharmacodynamics and patient outcomes? An observation from the Defyning Antibiotics Level in Intensive car unit patients (DALI) cohort. J Antimicrob Chemother 2016;71 (1): 196-207.

25. Conde-Estévez D, Grau S, Horcajada JP, Luque S. Off-label prescription of tigecycline: clinical and microbiological characteristics and outcomes. Int J Antimicrobial Agents 2010; 36 (5): 471-10.

26. Campbell TJ, Decloe M, Gill S, Ho G, McCready J, Powis J. Every antibiotic, every day: maximizing the impact of prospective audit and feedback on total antibiotic use. Plos One 12 (5): e0178434.

27. Rieg S, Küpper MF. Infectious diseases consultations can make the difference: a brief review and a plea for more infectious diseases specialists in Germany. Infection 2016; 44 (2): 159-66.

28. Hamandi B, Husain S, Humar A, Papadimitripoulos EA. Impact of infectious disease consultation on the clinical and economical outcomes of solid organ transplant recipients admitted for infectious complications. Clin Infect Dis 2014; 59 (8): 1074-82.

29. Paulsen J, Solligard E, Damas JK, DeWan A, Asvold BO, Bracken MB. The impact of infectious diseases specialist consultation for Staphylococcus aureus bloodstream infections: A systematic review. Open Forum Infect Dis 2016; 3: ofw048.

30. Butt AA, Al Kaabi N, Saifuddin M, Krishnanreddy KM, Khan M, Jasim WH et al. Impact of infectious diseases team consultation on antimicrobial use, length of stay and mortality. Am J Med Sci 2015; 350 (3): 191-4.

31. Sasikumar M, Boyer S, Remacle-Bonnet A, Ventelou B, Brouqui $\mathrm{P}$. The value of specialist-care infectious disease specialist referrals-why and for whom? A retrospective cohort study in a French tertiary hospital. Eur J Clin Microbiol Infect Dis 2017; 36 (4): 625-33.

32. Chirillo F, Scotton P, Rocco F, Rigoli R, Borsatto F, Pedrocco A, et al. Impact of a multidisciplinary management strategy on the outcome of patients with native valve infective endocarditis. Am J Cardiol 2013; 112 (8): 1171-6. 